"Moderating effect of internal control system to determinants influencing the financial statement disclosure"

\begin{tabular}{|c|c|}
\hline AUTHORS & $\begin{array}{l}\text { Khoirul Aswar (i) } \\
\text { Jumansyah Jumansyah } \\
\text { Sri Mulyani } \\
\text { Mahendro Sumardjo }\end{array}$ \\
\hline ARTICLE INFO & $\begin{array}{l}\text { Khoirul Aswar, Jumansyah Jumansyah, Sri Mulyani and Mahendro Sumardjo } \\
\text { (2021). Moderating effect of internal control system to determinants influencing } \\
\text { the financial statement disclosure. Investment Management and Financial } \\
\text { Innovations, 18(3), 104-112. doi:10.21511/imfi.18(3).2021.10 }\end{array}$ \\
\hline DOI & http://dx.doi.org/10.21511/imfi.18(3).2021.10 \\
\hline RELEASED ON & Monday, 09 August 2021 \\
\hline RECEIVED ON & Thursday, 20 May 2021 \\
\hline ACCEPTED ON & Tuesday, 03 August 2021 \\
\hline LICENSE & $\begin{array}{l}(c) \text { EY } \\
\text { This work is licensed under a Creative Commons Attribution } 4.0 \text { International } \\
\text { License }\end{array}$ \\
\hline JOURNAL & "Investment Management and Financial Innovations" \\
\hline ISSN PRINT & $1810-4967$ \\
\hline ISSN ONLINE & $1812-9358$ \\
\hline PUBLISHER & LLC "Consulting Publishing Company "Business Perspectives" \\
\hline FOUNDER & LLC "Consulting Publishing Company "Business Perspectives" \\
\hline
\end{tabular}

NUMBER OF REFERENCES

34
NUMBER OF FIGURES

0
NUMBER OF TABLES

3

(C) The author(s) 2021. This publication is an open access article. 


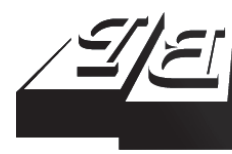

\section{BUSINESS PERSPECTIVES}

(O)

LLC "CPC "Business Perspectives" Hryhorii Skovoroda lane, 10, Sumy, 40022, Ukraine www.businessperspectives.org
Received on: $20^{\text {th }}$ of May, 2021 Accepted on: $3^{\text {rd }}$ of August, 2021 Published on: $9^{\text {th }}$ of August, 2021

(c) Khoirul Aswar, Jumansyah Jumansyah, Sri Mulyani, Mahendro Sumardjo, 2021

Khoirul Aswar, PhD, Lecturer, Economics and Business Faculty, Accountancy Department, Universitas Pembangunan Nasional Veteran Jakarta, Indonesia. (Corresponding author)

Jumansyah Jumansyah, Lecturer, Economics and Business Faculty, Accountancy Department, Universitas Al Azhar Indonesia, Indonesia.

Sri Mulyani, Lecturer, Economics and Business Faculty, Accountancy Department, Universitas Sumatera Utara, Indonesia.

Mahendro Sumardjo, Dr, Lecturer, Economics and Business Faculty, Accountancy Department, Universitas Pembangunan Nasional Veteran Jakarta, Indonesia.

This is an Open Access article, distributed under the terms of the Creative Commons Attribution 4.0 International license, which permits unrestricted re-use, distribution, and reproduction in any medium, provided the original work is properly cited.

Conflict of interest statement Author(s) reported no conflict of interest

Khoirul Aswar (Indonesia), Jumansyah Jumansyah (Indonesia), Sri Mulyani (Indonesia), Mahendro Sumardjo (Indonesia)

\title{
MODERATING EFFECT OF INTERNAL CONTROL SYSTEM TO DETERMINANTS INFLUENCING THE FINANCIAL STATEMENT DISCLOSURE
}

\begin{abstract}
This study examines whether the internal control system moderates the relationship among budget expenditure, government size, legislative size, and audit findings on financial statement disclosure in Indonesia. This is a quantitative study that uses the purposive sampling technique to collect data from 240 local governments in Indonesia. Data were analyzed using Structural Equation Modelling (SEM) with Smart PLS. The results show that government size, legislative size, and audit findings had a positive and significant effect on financial statement disclosure, whereas budget expenditure does not. In addition, the findings revealed that the internal control system moderates the relationship between government size and legislative size and financial statement disclosure, but not by audit findings. The study contributed to extending the institutional and agency theory that explains these factors toward disclosure in the local government in Indonesia. The findings suggest that Indonesia's local governments consider potential factors regarding increasing pressure to carry out disclosure of financial statements, as well as increasing the proper disclosure required by applicable Indonesian regulations.
\end{abstract}

Keywords

JEL Classification

\section{INTRODUCTION}

Every government in Indonesia, both regional and central, is to be more independent in the implementation of compiling its financial statements based on law No. 32 as of 2004, replaced by law No. 23 as of 2014, concerning regional government. Law No. 17 as of 2003 ensures that regional government submits a more detailed accountability report for the implementation of the National or Local Budgetary Revenue and Expenditure (APBN /APBD). Government Regulation (PP) No. 71 as of 2010 reveals that Government Accounting Standards (SAP) is the principle for expanding quality and accountability regarding most government performance (Aswar \& Saidin, 2018). SAP is commonly used by the government in conjunction with the guidelines requiring the process of structuring and presenting financial statements and expanding disclosure attachments.

The information generated by accrual-based accounting standards is considered superior when compared to cash-based standards. This is because accrual information is considered more able of providing an accurate picture of all financing and service provisions. According to Firmansyah et al. (2020), the presentation of accru- 
al-based financial statements is intended to present reliable financial statements to provide better benefits for stakeholders, both users and auditors of government financial statements.

Mandatory disclosure and voluntary disclosure are two types of disclosure (Handoko et al., 2018). Mandatory disclosures are part of SAP, which has the intention of creating transparency and accountability. Therefore, the resulting government financial reports must follow the latest SAP, which is following PP No. 71 as of 2010. Aside from that, the Supreme Audit Board (BPK) released the Summary of Semester Inspection Results (IHPS) II as of 2019, which contains the results of the review of 397 local government examination items. The test results include 238 performance test results and 159 test results for specific purposes. The BPK also provided data on Local Government Financial Statement (LKPD) problems in 2018. The data stated that there were 12,117 total problems in 2018. There were a total of 6,259 cases regarding compliance issues and 5,858 other cases regarding weaknesses in the internal control system.

This study is based on what had been done previously regarding the measurement of the level of disclosure. For example, Orin (2017) stated that the average financial statement disclosure is $93 \%$. Meanwhile, Bakar and Saleh (2011) found that the disclosure of financial statements under study had an average of 45.9\%. In Indonesia, Marsella and Aswar (2019) stated that the average LKPD disclosure rate on the island of Sumatra is $82.7 \%$. Another similar study conducted by Budiarto and Indarti (2019) examined the level of LKPD disclosure in Central Java with an average of $52.58 \%$. Based on the results that can describe the awareness of the implementation of LKPD disclosure levels, it can be stated that it is still quite low.

This shows that the regional government has not fully disclosed the mandatory disclosure items in its financial statements. Following agency theory, local government management must be monitored to ensure that management is carried out in full compliance with various applicable laws, regulations, and cases regarding the level of LKPD compliance with statutory provisions that are still common in government agencies in Indonesia.

\section{LITERATURE REVIEW}

Suwardjono (2014) explained conceptually that transparency is an integral part of financial statements. Evans (2003) illustrated that the submission of information in a financial statement, including the report itself, notes to the report and additional information related to the report is called disclosure, such that public management statements or disclosures not related to financial statements are excluded from the definition of disclosure. Several factors are considered to have risks related to the disclosure of financial statements, namely, budget expenditure. Law No. 58 as of 2005 concerning regional financial management states that regional spending is the obligation of local governments, which is recognized as a reduction in net worth (Arifin, 2020).

Aljifri et al. (2014) conducted a study on disclosure using a measurement based on 317 disclosure items in IFRS and items required by regulators in the
United Arab Emirates; the items are then adjusted for each sector. Furthermore, Arifin (2014) used measurements regarding PP No. 24 as of 2005 and included 57 items that have been adjusted. Dewata et al. (2020) used measurements based on PP No. 71 as of 2010 concerning SAP, and as many as 53 items. Kanapickiene et al. (2019) used the disclosure quality index (DQI) indicator by revealing that information on tangible assets has increased according to the DQI component. With the formation of the scale DQI $=0$ if no information is disclosed and DQI = 100 if the information is fully disclosed. Apart from that, Nor et al. (2019) measured online disclosure using a binary variable or dichotomy, namely 0 for not reporting and 1 for reporting. Furthermore, Murdayanti et al. (2014) used measurement with item indicators taken from Regulation No. 24 as of 2005 on SAP. Meanwhile, Marsella and Aswar (2019) used 50 items based on the government compliance index (CGI) to measure the level of disclosure. 
The local government management budget is a regional budget that contains all activities and programs carried out in one fiscal year in the form of guidelines related to the assessment of activities under government regulations. Local governments that have autonomy rights to manage local government budgets must be able to use the resources owned by the regions to realize prospects and meet the expectations and interests of the community. Local government budget expenditure is a financial work plan stated in one party that is contained in the maximum amount of expenditure in financing the interests of the state for the future as well as the estimated revenue received in a certain period to the other party. Patrick (2007) argued that higher local government spending budgets support citizens to get better information about local government activities. Arifin (2020) mentioned that, with the increasing local government budget expenditure, the local government should provide better service quality to the public, especially in disclosing financial information because this is related to financial accountability and transparency of local government to the public.

Patrick (2007) defined size as a component of organizational structure. An entity's size can be defined using a set of parameters. The bigger the assets, the bigger the local government. The greater the number of assets in the public sector, meaning that the scale of the municipal government is growing larger, the more services are used, necessitating greater accountability. In this case, the government, which has a large size, can carry out transparency, which is expected to establish accountability, which is shown through broader disclosure of information.

According to Hardiningsih et al. (2019), the legislative size is the Indonesian Parliament (DPR). As the people's representative, the legislature has a supervisory function, namely, ensuring the implementation of a good government system so that it is in line with the expectations of the community, controlling the implementation and reporting of financial information on its local government. The larger the local government size, the more complete the presentation of financial information, besides that a large local government size is usually increasingly known by the public so that it has complex financial management; thus, government can be monitored more closely related to transparency and accountability (Hardiningsih et al., 2020). Furthermore, the great- er the government size, the more complete the presentation of financial information; it will be improving a good internal control system as well.

The legislative size is the Indonesian government system that acts as a controlling body that can approve or even reject certain changes. The DPRD is given significant responsibility for matters related to the budget. The law on regional governance in Indonesia is law No. 23/2014. The law emphasizes that the DPRD has legislative, budgeting, and supervisory functions. Purnama and Alfina (2019) showed that the government size has a positive impact on LKPD disclosure. Contrary to what Baimukhamedova et al. (2017) found, the government size has no significant impact on the disclosure. The DPRD as the representative of the community has a function to ensure that budgets are allocated appropriately and ensure transparency and accountability by local government oversight. In this case, the DPRD will track and report on regional government financial information while also monitoring the implementation of government activities in accordance with the people's aspirations. The DPRD is also deeply involved in making day-to-day policies and regulations for all district service responsibilities.

The more legislative institutions in a region, the higher level of openness will be (Aswar, 2019). Laupe et al. (2018) stated that the size of the regional representative council in each region varies depending on the number of people in the area. Furthermore, the DPRD's position as financial supervisor is working well, allowing it to keep a tight grip on regional financial policies in terms of cost, performance, effectiveness, transparency, and accountability. The greater number of legislative members, the greater the degree of oversight exercised by the legislative members to enable local governments to disclose more information.

In Indonesia, BPK conducts audits of government financial reports. The audit involves checking the internal control system as well as compliance with laws and regulations to provide fair assurance that the financial statements are free of material misstatement. The audit opinion is focused on an evaluation of SAP enforcement, disclosure adequacy, legal and regulatory compliance, and the efficacy of the internal control system implementation. The internal control mechanism of the organization is struc- 
tured to provide sufficient assurance that the financial statements are accurate (COSO, 1992; INTOSAI, 2004). The internal control system evaluation report provides information about the extent to which the existing internal control system provides adequate assurance. While the BPK audit report does not express an opinion on the efficacy of the internal control system's implementation, the system's weaknesses point to the system's quality

Audits conducted by the Internal Audit Standards (SAI) aim to detect and ensure the reliability and fairness of the financial statements so that they are free from material errors and misstatements that will affect financial statements (Agustina \& Setyaningrum, 2020). After conducting the audit, SAI will then compile an audit report explaining the financial reporting problems consisting of opinions, along with findings and recommendations. Financial reports are audited to increase the accuracy of government financial reports in terms of transparency and accountability. Laupe et al. (2018) stated that the greater the number of audit findings, the more disclosure is needed.

Furthermore, Nor et al. (2019) stated that additional disclosure was made in an attempt to manage and correct the audit findings discovered by the $\mathrm{BPK}$, as well as to show the public the quality progress made by the local government in response to the BPK's recommendation so that it could be inferred that there are more findings. The results of the BPK examination will have an impact on the disclosure made by the agency. Furthermore, audit findings are anomalies, violations, or irregularities discovered by the auditor based on the findings of the audits. The internal control system has a strong relationship with the number of audit findings. This is under the BPK audit with the PP No. 01 as of 2007 concerning State Financial Audit Standards to provide an opinion on the impropriety of financial information presented in the financial statements of local governments.

The purpose of this paper is to determine whether an internal control system moderates the relationship between factors on the disclosure of the financial statements in order to develop appropriate policies for Indonesian local governments to improve the quality of information disclosed and serve as the foundation for developing countries such as Indonesia.

\section{HYPOTHESIS DEVELOPMENT}

The research hypotheses were developed using a combination of disclosure theory and experimental evidence. The internal control system is one of the most important determining criteria for financial statement disclosure. The theoretical outline of the agency theory shows how determining elements affect the financial statements' disclosure. The following hypotheses are presented when taken together:

H1: Budget expenditure has a positive effect on financial statement disclosure.

H2: Local government size has a positive effect on financial statement disclosure.

H3: Internal control system moderates the relationship between government size and financial statement disclosure.

H4: Legislative size has a positive effect on financial statement disclosure.

H5: Internal control system moderates the relationship between legislative size and financial statement disclosure

H6: Audit findings have a positive effect on financial statement disclosure.

H7: Internal control system moderates the relationship between audit findings and financial statement disclosure.

\section{METHODOLOGY}

The population is the local government financial statements Indonesia, which consist of 98 cities and 416 district governments with a total of 514 LKPD. The sampling technique used in this study is the purposive sample method. The sample criteria include: (a) financial statements audited by the BPK in 2019, (b) financial reports include budget realization statements, reports of changes in excess budget balances, operational statements, changes in equity statements, cash flow statements, balance sheets, and notes to financial statements, and 
(c) availability of data to measure variables.

Financial statement disclosure adopted from Marsella and Aswar (2019) uses a disclosure item with a total of 50 items based on the government compliance index described in PP No. 71 as of 2010 in accordance with SAP. The indicator used is the total number of items that must be available at the LKPD divided by the highest number of applicable items. Each item in the financial statements is checked and coded " 1 " if disclosed and " 0 " if not disclosed, and the percentage ratio for the indicator is in the range of $0 \%$ to $100 \%$. Government expenditure is measured by the total budget expenditure and government size using total assets (Gore, 2014). Furthermore, the number of DRPD members is used to measure the variable number of legislative sizes (Martinsen \& Jørgensen, 2010). The measurement of the audit findings is the number of items on the audit findings of local government. Lastly, the quality of internal control systems, measured by the log of the inverse of a number of internal control weaknesses found. The analysis used in this study is SEM using PLS version 3.0.

\section{EMPIRICAL RESULTS AND DISCUSSION}

The object comes from the research population, namely, local governments of districts and cities throughout Indonesia in the 2018 fiscal year. The number of samples affected by outliers is 39 district/city governments. The final sample that was obtained after the outliers were 240 district/city governments (Table 1).

Table 1. Summary of the final sample

\begin{tabular}{l:c}
\multicolumn{1}{c}{ Criteria } & Source: Authors' elaboration. \\
\hline \multicolumn{1}{c}{ Total } \\
\hline Population & 514 \\
\hline Unavailability of data & 15 \\
\hline Governments of districts and cities that do not have & 220 \\
full data for the 2019 fiscal year & 39 \\
\hline Outlier & 240 \\
\hline Final sample & \\
\hline
\end{tabular}

The statistical measures used in explaining the data of this study are the mean and standard deviation (Table 2). The mean is the average value of the data obtained and the standard deviation is the value that determines the distribution of data in the sample. Muhammad et al. (2010) suggested using the mean in interpreting the characteristics of the research data. Mean values less than 2.33 are categorized as low, 2.33-3.67 are considered as moderate, and more than 3.67 are considered as high. Table 2 shows the results of descriptive statistics. The average level of LKPD disclosure of district/city governments in Indonesia is 0.824 or around $82.4 \%$. Thus, the absence of local governments in Indonesia indicates that disclosure is mandatory at $100 \%$.

Table 2. Summary of descriptive statistic

Source: Authors' elaboration

\begin{tabular}{|c|c|c|c|c|c|}
\hline Variables & $\mathbf{N}$ & Min & Max & Mean & $\begin{array}{l}\text { Std. } \\
\text { Dev }\end{array}$ \\
\hline $\begin{array}{l}\text { Financial statement } \\
\text { disclosure (FSD) }\end{array}$ & 240 & 0.752 & 0.883 & 0.824 & 0.0457 \\
\hline $\begin{array}{l}\text { Budget expenditure } \\
\text { (BE) }\end{array}$ & 240 & 37.871 & 42.847 & 40.473 & 0.463 \\
\hline Government size (GS) & 240 & 34.924 & 33.395 & 33.745 & 0.395 \\
\hline Legislative size (LS) & 240 & 18 & 50 & 33.70 & 0.873 \\
\hline Audit findings (AF) & 240 & 5 & 20 & 14.785 & 3.538 \\
\hline $\begin{array}{l}\text { Internal control } \\
\text { system (ICS) }\end{array}$ & 240 & 4 & 46 & 16.67 & 4.378 \\
\hline
\end{tabular}

Furthermore, the objective of this study is to examine the budget expenditure, government size, the legislative size on the financial statement disclosure, and the internal control system as a moderating variable. The results of structural model data processing for path analysis coefficients obtained are seen in Table 3.

Table 3. PLS path algorithm and bootstrapping

Source: Authors' elaboration.

\begin{tabular}{|c|c|c|c|}
\hline Variable & $\begin{array}{c}\text { Path } \\
\text { Coefficient }\end{array}$ & $T$ Value & $P$ Values \\
\hline $\mathrm{BE} \rightarrow \mathrm{FSD}$ & -10.754 & -1.962 & 0.274 \\
\hline $\mathrm{GS} \rightarrow \mathrm{FSD}$ & 1.973 & 2.670 & 0.026 \\
\hline $\mathrm{LS} \rightarrow \mathrm{FSD}$ & 0.097 & 0.474 & 0.038 \\
\hline$A F \rightarrow F S D$ & -0.870 & 0.259 & 0.012 \\
\hline GS*ICS $\rightarrow$ FSD & 0.075 & 2.608 & 0.007 \\
\hline LS*ICS $\rightarrow$ FSD & 0.078 & 2.474 & 0.005 \\
\hline $\mathrm{AF}^{*} \mathrm{ICS} \rightarrow \mathrm{FSD}$ & 0.243 & 1.264 & 0.545 \\
\hline
\end{tabular}

The results in Table 3 indicate that budget expenditure had no significant relationship with financial statement disclosure. It is believed that when more local government budget expenditure is issued, it does not provide good public services and does not encourage the government to disclose information in LKPD. This study is in line with Arifin (2014) ex- 
amining local government financial reports in Java and outside Java by stating that local government budget expenditure insignificant relationship with disclosure. This means that this study does not support coercive isomorphism, because for the local government in carrying out its duties there is no pressure exerted by the central government in disclosing better information related to the quality of financial reports, causing a decrease in public demand for disclosure of financial statements in the form of basic services, education, health, social facilities, public facilities and developing social security.

Table 3 shows that government size had a significant and positive relationship with financial statement disclosure. This result is consistent with Rahman and Sobhan (2020), who believed that disclosure is positively associated with firm size. Thus, the larger a region's assets are, the larger its local government would be. The scale of a local government encourages an agency to make a comprehensive presentation. This study is in line with agency theory because a large local government size can guarantee that local governments have carried out their duties and responsibilities in managing regional finances in an accountable and transparent manner regarding SAP to the community. Local governments with a broad overall asset base have no difficulty tracking and handling funds, making local governments easy to disclose.

Based on Table 3, this study indicates that legislative size had a positive and significant effect on financial statement disclosure. This means that the bigger the legislative size in a region, the higher the disclosure level. The results are consistent with coercive isomorphism due to pressure within the central government against local governments in terms of tightening local government financial supervision, where local governments are responsible for financial reports quality needed to increase transparency and disclose accounting information under applicable regulations. This study supports Keerasuntonpong et al. (2015) who found that legislative size has a significant effect on disclosure in New Zealand. Another reason is that the community's representative has a supervisory role, namely, monitoring the government's operations so that they are always in line with the community's aspirations, as well as supervising the implementation and reporting of local government financial information to foster a culture of transparency and accountability. Supervision is one of the main functions inherent in the DPRD in addition to its legislative and budgetary functions. This is also supported in law No.32 as of 2004, article 184 , regarding the accountability for implementing the APBD paragraph 1 , which states that the regional head submits a local regulation on the responsibility for implementing the APBD to DPRD in the form of financial reports that have been audited by the BPK no later than six months after the fiscal year. Thus, the greater number of DPRD members will put greater pressure on local governments to make full disclosures.

The result findings indicate that audit finding has a positive and significant effect on financial statement disclosure. This study supports Martani and Liestiani (2010) who found that audit findings have a positive relationship with the local government disclosure. It is believed that the more audit finding, the more disclosure the government has to do. This study is in line with agency theory; the high number of audit findings in some district/city governments means good financial information disclosure. This can be explained because the number of findings proxied by the number of cases can illustrate disclosure. The number of audit findings can represent the true number because a large number of audit findings is of course material value. So that a large number of audit findings requires follow-up or disclosure presentation in a note of the financial statement and vice versa, the small number of audit findings certainly requires follow-up or disclosure presentation in a note of the financial statement.

The results of this study indicate that $\mathrm{H} 5$ is accepted. The internal control system is able to moderate the relationship between government size and financial statement disclosure. Internal control refers to an organization's strategy as well as all coordination methods and measures used in a sector or organization to safeguard properties, ensure the quality and reliability of accounting data, increase operation performance, and adhere to existing managerial policies. Internal control has the task of safeguarding assets as one of its roles. In this study, the size of local governments is measured by the total assets of local governments. This ensures that effective internal controls would be able to safeguard local government assets while still allowing them to be disclosed in financial reports. 
The results indicate that $\mathrm{H} 6$ is accepted; the internal control system can moderate the relationship between the legislative size and financial statement disclosure. The DPRD, as a statutory body, has a supervisory function over municipal budgets, ensuring that local governments adequately administer the current budget. A large number of DPRD members will increase local government oversight, resulting in more financial information being disclosed by local governments. A region with a significant number of DPRD members and a strong internal control structure would see an increase in financial statement transparency.
Table 3 shows that $H 7$ is rejected. The internal control system does not moderate the relationship between audit findings and financial statement disclosure. The number of audit results is unrelated to the internal control system's effectiveness. This is not in accordance with the explanation of Suwanda (2013), who believed that the BPK audit is carried out following BPK regulation No. 01 as of 2007 concerning state financial auditing requirements to offer an opinion on the accuracy of financial data contained in government financial reports.

\section{CONCLUSIONS AND RECOMMENDATIONS}

The study about disclosures is relatively new, with numerous arguments for why the local government is required to provide mandatory information, such as financial statement disclosure. This study assesses how Indonesian local governments deal with accounting compliance with government regulations using disclosure of financial statements by looking at the factors that influence it, namely, budget expenditure, government size, legislative size, audit findings, and internal control system as a moderating factor. The findings show that the local government has the most effective role over the disclosure of the 240 districts/cities. This study concluded that the internal control system moderates the relationship between 2 variables including government size and legislative size. This indicates that good internal control will increase disclosure of financial statements because supervision is the main function inherent in local government legislation and budgets.

This study has implications for local governments in Indonesia, namely, it considers potential factors related to increased pressure on the government in implementing financial statement disclosures. Utilization of information technology in meeting social demands that is more efficient and effective is one of the strategies for regional governments in implementing financial statement disclosure. In addition, local governments must emphasize the importance of an internal control system because it can increase financial statement disclosure in Indonesian local governments. Further research should extend the longitudinal analysis and could be conducted in other jurisdictions, for example, other countries (in Asia and around the world). In addition, the GCI measurement objects could be modified.

\section{AUTHOR CONTRIBUTIONS}

Conceptualization: Khoirul Aswar, Jumansyah Jumansyah.

Data curation: Khoirul Aswar, Sri Mulyani, Mahendro Sumardjo.

Formal analysis: Khoirul Aswar, Jumansyah Jumansyah.

Investigation: Sri Mulyani, Mahendro Sumardjo.

Methodology: Khoirul Aswar, Jumansyah Jumansyah, Sri Mulyani.

Resources: Khoirul Aswar, Sri Mulyani, Mahendro Sumardjo.

Software: Khoirul Aswar, Jumansyah Jumansyah.

Supervision: Khoirul Aswar.

Validation: Khoirul Aswar, Jumansyah Jumansyah, Sri Mulyani.

Visualization: Jumansyah Jumansyah, Mahendro Sumardjo.

Writing - original draft: Khoirul Aswar.

Writing - review \& editing: Jumansyah Jumansyah, Sri Mulyani. 


\section{REFERENCES}

1. Agustina, N., \& Setyaningrum, D. (2020). Determinants quality of local government financial statements in Indonesia. Review of Integrative Business \& Economics Research, 9(3), 226-239. Retrieved from http://buscompress.com/uploads/3/4/9/8/34980536/riber_9s3_20_a20-111_226-239.pdf

2. Agustiningsih, S. W., Murni, S., \& Putri, G. A. (2017). Audit findings, local government characteristics, and local government financial statement disclosure. Review of Integrative Business \& Economics Research, 6(3), 179-187. Retrieved from http://buscompress.com/ uploads/3/4/9/8/34980536/riber_6-3_a17-121_179-187.pdf

3. Aljifri, K., Alzarouni, A., \& Tahir, M. I. (2014). The association between firm characteristics and corporate financial disclosures: evidence from UAE companies. The International Journal of Business and Finance Research, 8(2), 101-124. Retrieved from http://www.theibfr2.com/RePEc/ ibf/ijbfre/ijbfr-v8n2-2014/IJBFRV8N2-2014-8.pdf

4. Arifin, J. (2014). Isomorphic pressures influencing the level of mandatory disclosure within financial statements of Indonesian local governments (Doctoral Thesis). Curtin University. Retrieved from http://hdl.handle. net/20.500.11937/2046.

5. Arifin, J. (2020). Disclosure of financial statements on the website: An empirical study in Indonesian local governments. Review of Integrative Business \& Economics Research, 9(2), 174-188. Retrieved from https://search. proquest.com/docview/236774062 0 ? accountid $=17242$

6. Aswar, K. (2019). Financial Performance of Local Governments in Indonesia. European Journal of Business \& Management Research, 4(6), 1-6. https://doi.org/10.24018/ ejbmr.2019.4.6.164

7. Aswar, K., \& Saidin, S. Z. (2018). Accrual accounting adoption in java municipalities: An empirical investigation. International Journal of Business \& Economic Sciences Applied Research (IJBESAR), 11(3), 24-30. Retrieved from https://ideas.repec.org/a/tei/ journl/v11y2018i3p24-30.html

8. Baimukhamedova, A., Baimukhamedova, G., \& Luchaninova, A. (2017). Financial disclosure and the cost of equity capital: The empirical test of the largest listed companies of Kazakhstan. The Journal of Asian Finance, Economic and Business, 4(3), 5-17. https://doi. org/10.13106/jafeb.2017.vol4. no3.5

9. Bakar, N. B. A., \& Saleh, Z. (2011). Disclosure of accountability information in public sector: The case of Malaysian Federal Statutory Bodies. $13^{\text {th }}$ Comparative International Governmental Accounting Research (CIGAR) Conference. Ghent, Belgium. Retrieved from https://www. researchgate.net/publication/215487678_Disclosure_of_ Accountability_Information_in_ Public_Sector_The_Case_of_Malaysian_Federal_Statutory_Bodies

10. Budiarto, D. S., \& Indarti, L. (2019). Do the characteristics of local government affect the disclosure of local government financial statements? Jurnal Akuntansi Bisnis, 12(1), 19-31. (In Indonesian). https://doi. org/10.30813/jab.v12i1.1549

11. Committee of Sponsoring Organizations of the Treadway Commission (COSO). (1992). Internal Control-Integrated Framework.

12. Dewata, E., Jauhari, H., Aprianti, S., \& Hijria, E. N. (2018). The effects of local government characteristics and audit opinion on the performance of district and city governments in Indonesia. Jurnal Dinamika Akuntansi dan Bisnis, 5(2), 151-162. https://doi. org/10.24815/jdab.v5i2.9057

13. Evans, T. G. (2003). Accounting Theory - Contemporary Accounting Issue. USA: Sounth Western.
14. Firmansyah, A., Wibowo, P., \& Puspitarini, I. (2020). Implementation of accrualbased accounting on regional property in Indonesia: Competence employees and organizational commitments perspective. International Journal of Psychosocial Rehabilitation, 24(7), 9502-9512. Retrieved from https://www.researchgate.net/ publication/340923121_Implementation_of_Accrual_Based_Accounting_on_Regional_Property_ in_Indonesia

15. Gore, A. K. (2014). The effects of GAAP regulation and bond market interaction on local government disclosure. Journal of Accounting and Public Policy, 23(1), 23-52. https://doi.org/10.1016/j. jaccpubpol.2003.11.002

16. Handoko, F., Pamungkas, V., Syakhroza, A., \& Hermawan, A. (2018). Moderating effect of press highlights on the effect of the quality of internal control systems on disclosure in local government financial reports. Advance in Economic, Business and Management Research, 89, 476484. https://dx.doi.org/10.2991/ apbec-18.2019.67

17. Hardiningsih, P., Januarti, I., Srimindarti, C., \& Oktaviani, R. M. (2019). Does the characteristics of regional government and complexity affect on the disclosure regional financial statements? Jurnal Akuntansi \& Auditing Indonesia, 23(2), 107-116. https:// doi.org/10.20885/jaai.vol23.iss2. art5

18. Hardiningsih, P., Udin, U., Masjojo, G., \& Srimindarti, C. (2020). Does Competency, Commitment, and Internal Control Influence Accountability? The Journal of Asian Finance, Economic and Business, 7(4), 223-233. https://doi.org/10.13106/ jafeb.2020.vol7.no4.223

19. INTOSAI. (2004). Guidelines for Internal Control Standards for the Public Sector. Brussels, Belgium. Retrieved from https://ms.hmb. gov.tr/uploads/2019/06/6883- 
A22DF8F253B907C7599ED7639A374C05765D2DC7.pdf

20. Kanapickiene, R., \& KeliuotyteStaniuleniene, G. (2019).

Disclosure of non-current tangible assets information in local government financial statements: The case of Lithuania. Economies, 7(4), 116. https://doi.org/10.3390/economies7040116

21. Keerasuntonpong, P., Dunstan, K., \& Khanna, B. (2015). Factors influencing disclosures of statements of service performance of New Zealand local authorities. Pacific Accounting Review, 27(3), 304328. https://doi.org/10.1108/ PAR-02-2014-0005

22. Laupe, S., Saleh, F. M., Ridwan, \& Mattulada, A. (2018). Factors influencing the financial disclosure of local governments in Indonesia. Academy of Accounting and Financial Studies Journal, 22(3), 1-9. Retrieved from https://www.abacademies. org/articles/Factors-Influencingthe-Financial-Disclosure-ofLocal-Governments-in-Indonesia-1528-2635-22-3-244.pdf

23. Marsella, C., \& Aswar, K. (2019). An investigation of financial statement disclosure in local government financial statements. International Journal of Business and Economic Affairs, 4(6), 273281. Retrieved from http://www. ijbea.com/ojs/index.php/ijbea/ article/view/127

24. Martani, D., \& Liestiani, A. (2010). Disclosure of Local Government Financial Statements in Indonesia. 22 $2^{\text {nd }}$ Asian - Pacific Conference on International Accounting Issues. Gold Coast, Australia. Retrieved from https://staff.blog.ui.ac. $\mathrm{id} / \mathrm{martani} /$ files/2016/07/BFB2c1-1-Disclosure-of-LocalGovernment...-Dwi-Martani.pdf

25. Martinsen, D. S., \& Jørgensen, T. B. (2010). Accountability as a differentiated value in supranational governance. The American Review of Public Administration, 40(6),
742-760. https://doi.org/ $10.1177 \% 2 \mathrm{~F} 0275074010366300$

26. Muhammad, N., Maheran, N., Jantan, M., \& Taib, F. (2010). Moderating effect of information processing capacity to investment decision making and environmental scanning. Business Management Quarterly Review, 1(1), 9-22. Retrieved from https://ir.uitm.edu.my/id/ eprint/860/

27. Murdayanti, Y., Gurendrawati, E., \& Iyabu, Y. F. (2014). Analysis of factors affecting level of disclosure in regional sector's financial statements. Review of Integrative Business \& Economics Research, 4(1), 253-261. Retrieved from http://buscompress.com/uploads/3/4/9/8/34980536/riber h14-198_253-261_.pdf

28. Nor, W., Hudaya, M., \& Novriyandana, R. (2019). Financial statements disclosure on Indonesian local government websites: A quest of its determinant. Asian Journal of Accounting Research, 4(1), 112128. https://doi.org/10.1108/ AJAR-06-2019-0043

29. Orin, S. K. (2017). The effect of legislation on fourth amendment protection. 115 Michigan Law Review, 117. Retrieved from https://papers.ssrn.com/sol3/papers.cfm?abstract_id $=2819878$

30. Patrick, P. A. (2007). The determinants of organizational innovativeness: the adoption of GASB 34 in Pennsylvania local government (Thesis). The Pennsylvania State University. Retrieved from https://etda. libraries.psu.edu/files/final_submissions/4828

31. Purnama, H., \& Alfina, P. (2019). Which ones are more important: Characteristics or complexities? a study of the disclosure in local government financial reports. Journal of Business \& Information Systems, 1(2), 77-88. https://doi.org/10.36067/jbis. v1i2.24

32. Rahman, M.S., \& Sobhan, R. (2020). The Impact of Intellectual Capital Disclosure on Firm Performance: Empirical Evidence from Pharmaceutical and Chemical Industry of Bangladesh. The Journal of Asian Finance, Economic and Business, 7(2), 119-129. https:// doi.org/10.13106/jafeb.2020.vol7. no2.119

33. Suwardjono. (2014). Financial reporting engineering accounting theory ( $3^{\text {rd }}$ ed.). Yogyakarta: BPFE Yogyakarta.

34. Suwanda, D. (2013). Optimization of local government asset management. Jakarta: PPM Management. 